Winston churchill and his illnesses

\section{John Launer}

There are few public events that people still recall vividly after several decades have passed. For almost everyone of my generation, the state funeral of Sir Winston Churchill on 30 January 1965 is one of those memories. It took place at St Paul's Cathedral in London and was a day of pageantry that probably had no parallel since the funeral of the Duke of Wellington over a century earlier. Like most of the nation, our family watched it on television. At the end of the broadcast the BBC played 'God Save the Queen'. We all stood up from our armchairs, and remained standing to attention until it was finished. My parents had both been refugees from Europe; my father served in the Czech squadron of the Royal Air Force, and my mother had accompanied him to coastal bases around Britain. They had no doubt at all that they owed their survival directly, and personally, to the man they were now mourning.

We live in an age where the idea of standing to attention in one's living room during the national anthem has for most people become almost unimaginable. In the same way, no-one in any democratic country would regard any politician with the reverence in which Churchill was held until his death, even by most of his political opponents. Modern historians offer a view of Churchill's career that is far more nuanced than the one my parents' generation mostly held. ${ }^{12}$ Recent accounts acknowledge his genius and courage as a wartime statesman, but do not shy away from some of the darker sides of his military and political career. These include his role in the catastrophic invasion of Gallipoli in the First World War, his use of cavalry against Welsh strikers, his opposition to women's suffrage and Indian independence, and his rather late conversion to anti-fascism. At the same time, I remember there was a purity about the gratitude and awe that my family- and hundreds of millions of people like them around the world - held for him. In many ways it is sad that we have lost this.

A magnificent new volume focusing on Churchill's struggle with different illnesses over the course of his lifetime manages to recapture some of that purity. ${ }^{3}$ It does so without making it seem sentimental or

Correspondence to Dr John Launer, Associate Editor, Postgraduate Medical Journal, London, UK; johnlauner@aol.com anachronistic. Its authors are Allister Vale, a clinical pharmacologist, and John Scadding, a neurologist and former academic dean of the Royal Society of Medicine, as well as being the son of one of Churchill's own physicians. As medical historians rather than political ones, Vale and Scadding benefit from being able to describe the man through the words of those who were intimate with him as family members or friends, or who cared for him professionally. Almost without exception, these words were written or spoken with admiration and love. The book is a summation of many years of archival research into Churchill's medical history, done with the wholehearted support of Churchill's family, including his great-grandson Randolph, who has written an introduction. The subtitle of the book, 'Courage, Resilience and determination', may seem partisan when you first open the book. It does not seem so by the end.

\section{LIFE-THREATENING ILLNESSES}

Winston Churchill was born in 1874 and died shortly after his 90th birthday. I have no idea how many life-threatening illnesses and accidents the average man of 90 from the English upper classes might have faced in his era, especially one like Churchill who had tremendous stamina for most of the time. From Vale and Scadding's account, Churchill appears to have had at least the proverbial nine lives of a cat - as his personal physician Lord Moran sometimes pointed out. His first serious illness was pneumonia as a child, when the only treatment available was alcohol, used as a 'stimulant'. He had three further bouts of pneumonia as Prime Minister during the Second World War. On one of these occasions he was in north Africa, and his life was probably saved by sulphonamides provided by a US military hospital. It was only for its fifth occurrence, in the 1950 s, that penicillin was available. Following Churchill's first minor stroke in 1949 (which he and his physicians largely kept a secret) he appears to have had at least seven others before his final, fatal one. His surgical operations included an appendicectomy, repair of an inguinal hernia and - probably the most perilous of all at his age - repair of a fractured femur aged 87 at the Middlesex Hospital. This was followed by a femoral venous thrombosis and nearly 2 months of recuperation as an in-patient. An episode of chest pain on a visit to the White House in the war was originally diagnosed by Moran as a coronary, although Vale and Scadding show that it almost certainly was not. The catalogue of his other conditions includes recurrent dislocation of his right shoulder, salmonellosis, intermittent atrial fibrillation, two episodes of jaundice (one probably from a gallstone, the other possibly drug-induced), an arterial embolus of his right little finger, a crush fracture of his fifth thoracic vertebra, and persistent seborrhoeic dermatitis.

Churchill had two serious accidents that might easily have led to his premature death. Playing a game of tag as a teenager, he tried to evade his pursuers by jumping off a bridge onto the overhanging branch of a tree. Misjudging the distance, he fell 29 feet (around 9 metres) onto hard ground. His fall was probably slowed by branches, since he sustained only concussion and possibly two small cervical fractures that were only found in old age. In 1931, while on a speaking tour, of the United States, he stepped out into the busy New York traffic, but looked in the wrong direction (something that British pedestrians tend to do in countries where cars inconsiderately drive on the right.) He was knocked over by a car going at full speed. He was incredibly lucky to sustain fractures only to his nose, ribs, fingers and toes, together with a pleural haemorrhage and an assortment of lacerations, abrasions and bruises.

\section{EVIDENCE AND DOCUMENTATION}

Some previous biographers have promoted the idea that Churchill suffered from clinical depression and alcoholism. Vale and Scadding dismiss both diagnoses, in separate chapters devoted to each. Through a careful analysis of Churchill's own accounts and those of family, friends and physicians, they demonstrate that there was nothing in Churchill's moods or in his behaviour that would justify these labels. As they do throughout the book, they offer readers full evidence and documentation to support their views, but do so in a dispassionate way that would allow scope for dissenting opinions. My own view is that the semantic debates around whether Churchill had these conditions should encourage us to be more sceptical about much taxonomy in psychiatry generally.

Almost all the book is presented as a documentary history, with much of the text taken up by extensive quotations from medical records, correspondence, diaries and memoirs. These are nearly 
always connected together by enough narrative to contextualise each illness in relation to historical events and the individuals involved. Although this quilt-like style of biography may not meet with approval from every reader, it seems to me by far the most transparent approach from a reader's point of view. (I should declare an interest here, as the author of a modest biography where I chose a similar approach.) Each chapter ends with a useful section entitled 'Medical Aspects', offering a commentary from the point of view of 21 st century medicine. This allows the authors to separate the contemporaneous account from a more modern perspective.

Vale and Scadding adopt a generous stance towards what might appear like medical failings by some of the doctors who attended Churchill,. They point out at the beginning of the book how easy it is to be critical, but also offer the important comment: 'On so many occasions, they kept the great man going and ready to fight another day.' They are especially even-handed in relation to Lord Moran. Churchill's personal physician. Moran was subject to criticism during the war for travelling on so many international trips with his star patient, at the expense of his duties as president of the Royal College of Physicians and dean of St Mary's Hospital Medical School. After Churchill's death, his medical memoirs of his patient became controversial because of alleged inaccuracies and breaches of confidentiality. ${ }^{4}$ Vale and Scadding do not gloss over these issues, but nor do they make a meal out of them. Moran's overall care and friendship with Churchill were remarkable.

\section{VIVIDLY HUMAN PORTRAITS}

From among many vividly human portraits of Churchill by doctors, including some who became his friends, it is worth quoting this description of him by one of the surgeons who attended him, Brigadier Harold Evans:

"Churchill has the most fascinating chuckle, and his face, when he is pleased with a thought of his, or a situation conjured up by remarks of someone else, wrinkles up like a baby's - like Puck's. His eyes are dull - and the conjunctivae a little red, as though he had conjunctivitis. They can be hard as he looks at you - or as tender as a woman's - they can weep easily. I believe now the story of how he cried ... when he realised all was lost in France. He is emotional ... I think the right description is that he allows himself to react fully and without restraint and without troubling himself about what impression he makes on the onlookers. He is no actor, no poseur". 5

Vale and Scadding's book is now likely to serve as the definitive record of
Churchill as a patient. It is equally worth reading as an account of Churchill the man, with all his fierceness and proneness to tears, his inability to take advice and his willingness to forgive, his mischievousness and his generosity, and most of all his vulnerability and bravery.

\section{Twitter John Launer @JohnLauner}

Funding The authors have not declared a specific grant for this research from any funding agency in the public, commercial or not-for-profit sectors.

Competing interests None declared.

Patient consent for publication Not required.

Provenance and peer review Not commissioned; internally peer reviewed.

(C) Author(s) (or their employer(s)) 2021. No commercial re-use. See rights and permissions. Published by BMJ.

$$
\text { D Check for updates }
$$

To cite Launer J. Postgrad Med J 2021;97:135-136.

Postgrad Med J 2021;97:135-136.

doi:10.1136/postgradmedj-2020-139391

\section{REFERENCES}

1 Best G. Churchill: a study in greatness. London: Penguin Books, 2002.

2 Roberts A. Churchill: walking with destiny. London: Allen Lane, 2013.

3 Vale A, Scadding J. Churchill's IIInesses 1886-1965. Barnsley: Frontline Books, 2020.

4 Moran C. Winston Churchill: the struggle for survival 1940-1965. London: Constable, 1966.

5 Vale A, Scadding J. Churchill's Illnesses 1886-1965. Barnsley: Frontline Books, 2020: 159. 